\title{
Culture and Identities of Black People in Rio de Janeiro and São Paulo Carnivals on the Centenary of Slavery Abolition (1988)
}

\author{
Zélia Lopes da Silva*, Ynayan Lyra Souza \\ Department of History, São Paulo State University (UNESP), Assis, Brazil \\ Email address: \\ zelia.lopes@terra.com.br(Z. L. da Silva),ynayansouza@gmail.com (Y. L. Souza) \\ ${ }^{*}$ Corresponding author
}

\section{To cite this article:}

Zélia Lopes da Silva, Ynayan Lyra Souza. Culture and Identities of Black People in Rio de Janeiro and São Paulo Carnivals on the Centenary of Slavery Abolition (1988). History Research. Vol. 8, No. 2, 2020, pp. 48-58. doi: 10.11648/j.history.20200802.12

Received: June 29, 2020; Accepted: July 31, 2020; Published: August 19, 2020

\begin{abstract}
This article analyzes the representations of sambas-enredo (samba theme-songs) sung in the parades of the samba schools in Rio de Janeiro and São Paulo during the carnival of 1988, the centenary year of the abolition of slavery in Brazil. The focus of this text is, therefore, to apprehend the narratives of Afro-descendants present in the representations that were exhibited by the different associations during the carnivals in these cities, making comparisons with the positions of the black movement during these events. It is also interesting to establish the differences and common elements, which were coined in these readings made by black people about their centenary trajectory after the abolition. In the narratives of sambas-enredo, the particular and universal aspects of identity (or new forms of negotiation of tension between the two dimensions) were articulated and reaffirmed for Afro-descendants, based on the link established between past and present. Finally, what motives for these questions become the group's strategies? For this article, different types of sources were researched, such as the lyrics of sambas-enredo, the synopses, the photographs and the videos of television broadcasts of the parades that allowed us to view the allegories displayed on the streets, in addition to the specialized bibliography that covers the universe of Afro-descendants, before and after the abolition of slavery.
\end{abstract}

Keywords: Brazil, Carnival, Centenary of Slavery Abolition, Samba Schools, Samba-Enredo

\section{Introduction}

The discussion about the culture and identities of black people exhibited in the carnivals that took place in the cities of Rio de Janeiro and São Paulo, in the centenary of the abolition (1988), presents some challenges because they were, at the time investigated, manifestations that had their specificities and that were in different stages. Rio de Janeiro's carnivals were already recognized worldwide for the exuberance and luxury of their thematic parades, while those in São Paulo were still in the process of implementation and consolidation, being inspired by the Rio model, a process that extended to their samba schools.

Despite the differences from an aesthetic point of view and the traditions of the two cities' associations, there are convergent aspects that focus on the subculture of the group centered on samba and on the other common elements that define their ties of belonging, which were focused on the values of the African matrix to which black people identified themselves and that they wanted to maintain for the long term. In this case, the lessons of Jöel Candau, research reviewed by Letícia Matheus, are useful, considering that the author recognizes that "in the origin and in the events [are] the main temporal markers according to which the identity processes (the identification) are possible" [1].

In this context of the $1980 \mathrm{~s}$, it is necessary to consider the ongoing process of change that began to affect traditional cultural forms in the way of being and in the relations between black communities and samba schools. Some of them were the entrance of other social segments into their environments and the transformation of the associations into cultural companies, unlike the previous modus operandi that was anchored in the community. This seems to have given rise to concerns about the reaffirmation of their original 
identities, in the sense approached by Stuart Hall [2]. That is, the search for protection against the dilution of the cultural boundaries of the group, in the broader universe of Brazilian culture and the globalization of its surroundings.

In dialogue with other authors, Stuart Hall clarified that these changes have been ongoing since the 1970s in planetary terms, albeit with different dimensions, in central and peripheral countries. It was also exposed the conceptual foundations that allow the establishment of ties of belonging between individuals by stating that,

"All identities are located in a symbolic space and time [...] in invented traditions that link past and present, in origin myths that project the present back into the past, in nation narratives that connect the individual to broader and more important national historical events" [3].

In modernity, Stuart Hall noted, there was also the separation of space and place, a phenomenon that allowed the existence of "absent" relationships, distant (in terms of location), from any "face-to-face" interaction [3]. In the author's analysis, the places were entirely penetrated and shaped by social influences quite distant from them, which becomes problematic because it is in these fixed places that we have our "roots".

These issues permeated the conjuncture and the samba schools that experienced the dilemmas of following the tradition or incorporating other elements aimed at the spectacularization of their parades, shaped like a luxury carnival-show, to meet the demands of the television media.

It was in this context that the centenary of the abolition of slavery (1988) appeared in the samba school parades and became the subject of these reflections. Our aim was to apprehend the senses of the representations contained in sambas-enredo (samba theme-songs) that were exhibited during Momo's revelry in Rio de Janeiro and São Paulo capitals, about such a "memorial fact", as Paul Ricoeur [4] names it, and which crossed the times with their symbolism and controversy.

Under what conditions did these African descent men and women live after a hundred years of the slavery abolition? And their associations, what spaces did they occupy in these cities? The large specialized production indicates that the locations where the samba schools settled, both in Rio de Janeiro and São Paulo, had a poor infrastructure in terms of the various urban facilities — running water, sewage, efficient public transport, schools, hospitals, etc. - distinctly from the other neighborhoods where the middle and wealthy segments of these cities lived.

To get an idea of the magnitude of the problem, in the 1980s, 8,493,226 people lived in the various neighborhoods of São Paulo city, marked by deep inequalities. Rio de Janeiro was also a populous metropolis, with 5,183,992 inhabitants, most of them living on few resources in precarious housing. The unfavorable ambience experienced by black people in both cities is revealed in the neighborhoods where they live, deprived of basic urban facilities (running water, electricity, schools, leisure environments, etc.), which further increased their exclusion.
Even so, these shortcomings did not prevent them from triggering their cultural projects aimed at the carnival celebrations nucleated in the parades of samba schools that received the adhesion of people who lived in such locations.

What about the academic production related to black people in these hundred years after slavery abolition? It can be said that it is significant, although dispersed by different themes. Despite this, it is asymmetric compared to that which discusses the trajectory of slavery. The multiple aspects of the slavery world - in the 18th century in the Portuguese Colony in the Americas and, during the 19th, after its Independence - and the meanings of freedom that emerge throughout this process, were argued by several external researchers [5, 6]; and internally, by Brazilian intellectuals, whose research has brought significant contributions, in addition to training new generations of researchers on the tragic and endless slavery that lasted for more than three centuries in the country. [7-10].

The explanations about the post-abolition phase also brought clarifications about the colonial system and the situation of the black people, before and after slavery. The "legitimized" sociologists and interpreters of that phase, Gilberto Freire, Fernando Henrique Cardoso and Florestan Fernandes, turned to the transition from slave labor to free labor in the country, and barely commented on the black people themselves. These authors, leaving aside theoretical and political differences, according to their critics, reiterated that the difficulties of the black people were due to their "unpreparedness" to enter the free and formal labor market. After all, they were illiterate and did not have a profession because they came from the large coffee plantations. And, according to Cardoso, they had been passive during the process of their enslavement.

The questioning of these controversial explanations came from several authors, starting with the sociologist Clóvis Moura, in the book Rebeliões da Senzala: Quilombos, Insurreições e Guerrilhas (Slave Rebellions: Quilombos, Insurrections, Guerrillas), published in 1959, which paved the way for other researchers [8]. Moura goes further in this debate by questioning the passive view of the slave under the yoke of slavery. He defends the opposite, stating that

"the transition from slavery to free labor thus had, in the quilombola, the rebel element and that for this very reason denied the existing regime, a positive factor; as the slaves were embedded in the production process, they started to come to terms with it and produced more, it was a conservative element"'[11].

The forms of resistance of the black people are explored, in the excerpt of his conclusions about the quilombos and guerrillas, examining the forms of the slave's protest, which, according to his words,

"they can be listed as follows:

a) Passive types: 1) suicide, psychological depression (spleen); 2) the murder of their own children or other slaves; 3) individual escape; 4) collective escape; 5) the organization of quilombos far from cities.

b) Active types: 1) city revolts for the seizure of political 
power; 2) the guerrillas in the woods and roads; 3) participation in non-slave movements; 4) the armed resistance of quilombos to repressive invasions and 5) individual or collective violence against masters or overseers" [12].

Following in Moura's footsteps, more recently, the book Liberdade por um fio (Freedom by a thread), organized by João José Reis and Flávio dos Santos Gomes, exemplifies the dimension of the struggles of black people for their freedom. The various authors, experts on slavery, map the Quilombos spread throughout Brazil, demonstrating that they went far beyond Palmares, the best known of them. The organizers say that "where there was slavery there was resistance. Of various types" [13], the most common of which were escape and the formation of escaped slave groups. The individual escape could go to the cities or join a group, coming from individual or collective escape. This second type gave rise to the so-called Quilombos and Mocambos. Its members were named quilombolas or mocambeiros. In summary, the book deals with this "history of the search for freedom, full of pitfalls, conflicts and commitments, which the articles of the various authors seek to unveil, giving the complex panorama of slavery and black resistance" in the country.

Sílvia Lara, in the article Escravidão cidadania e história do trabalho no Brasil (Slavery, citizenship and the history of work in Brazil) [10] and George Andrews, in his book Negros e brancos em São Paulo (Black and white people in São Paulo) (1888-1988) [14], still arguing about the production that excluded black people from their liberation process and inclusion in Brazilian society, in the 1990s, bring other aspects. They disagreed with such reductionist interpretations that limited black people's view of freedom to their insertion into the free labor market.

Lara, rebutting the interpretations of sociologists Gilberto Freire, Fernando Henrique Cardoso, Florestan Fernandes and their followers, discusses the "myths" enshrined in this academic production, namely: the "slave as a thing"; who did not fight for his freedom; who remained outside the formal labor market after 1888 for his "technical unpreparedness"; and, yet, its absence, even in discussions about "work" in Brazil, with only free labor being discussed. In short, black people in these analyzes were treated again as a thing and not as subjects who intervened in their liberation process, in different ways.

The author argues that just before abolition there were at least three different positions of black people, in dispute, on the issue of freedom: to remain free in Quilombos; not to enter the world of work because they did not want to submit to any master; be free to form your family with a guarantee that your children would not be sold by anyone.

George Andrews, in the aforementioned book, did exhaustive research on the situation of Afro-Brazilians over a period of one hundred years, as free men and women, taking São Paulo, the richest state in the country, as the core of his analysis. The result of this long research makes it clear that black people have been left to their own devices. The arguments of the elites were that Brazilian laws did not obstruct their social ascension and, in this case, the problem was found in the black people themselves and their lack of ambition, laziness, loitering, among other aspects. The author covers several items such as the admission of black people (men and women) to education at all levels, as well as formal employment, in public service and private initiative, and access to real estate, such as land, marriages, delinquency/violence, from 1888 to 1988. In all these spheres, their insertion was difficult, including entry into the school system, due to prejudices, even if disguised. The recurring stigmas that they began to suffer were partly linked to the state of poverty of the majority of this population and to racial prejudices, camouflaged under the ideology of the "myth of racial democracy", defended by Gilberto Freire.

Thus, Andrews overturns the thesis of technical unpreparedness for being "illiterate and having no profession" by showing, among other aspects, that black people were inserted in the formal labor market from the beginning, in subordinate positions, for other reasons. The factory jobs were restricted with the massive influx of white European immigrants, as a result of political decisions by the elites who aimed to achieve with these measures the "whitening" of the country. Therefore, the problems stemmed from racist prejudices and the exclusion policies that followed, at all levels. The results reached by the author are discouraging and point to the unfinished "slavery abolition", a situation that is projected to other regions of the country and to contemporary times.

Moving on to the celebrations of the end of the hundred years of slavery, there are some reflections on the subject. George Andrews [15], for example, in the article "Mobilização política negra no Brasil, 1975-1990" (Black political mobilization in Brazil, 1975-1990) says that the engagement of black militants in the activities of the centenary of Abolition was broad. In this process of redemocratization and political effervescence brought about by the calling of the Constituente Assembly, the poets questioned aspects of their experiences in Brazilian society, regardless of political articulation or not with their peers.

Andrews, however, shows that the defense of the myth of racial democracy was prevalent in the country, even among the black movement. The author identifies, nevertheless, difficulties in maintaining this ideology, even during the 1980s:

"The 1980s were thus a favorable time for black activists to take on the national ideology of racial democracy, which they did in a variety of forums: public meetings and lectures, newspaper and editorial articles, debates and other resources on the radio and on TV, academic conferences and even festivals of popular songs and samba. These activities reached a climax during the centenary celebrations of the Abolition of slavery in May 1988. The content of these festivities, especially those not sponsored by the black movement, but by traditional institutions such as the Church, universities, and federal, state and municipal governments, makes it clear to what extent the national consensus on racial democracy had shattered during the 1980s" [16]. 
In the article "A abolição aboliu o quê?" (What did abolition abolish?) [17] written by the historian José Murilo de Carvalho - and published in the newspaper Folha de S. Paulo on the exact day when the signing of the Lei Áurea (Golden Law) celebrated its 100th anniversary - the author debated the meaning of "May 13". For him, it was a disputed date since different versions competed "for hearts and minds".

The author highlights three narratives about May 13: the "traditional", which presents Princess Isabel as the redeemer, and liberation as the result of a donation from the State (according to the historian, this version, despite surviving in some school booklets and in the popular imagination, would be doomed to extinction). In opposition to this, there is also the defense of "cursed May 13", which treats the date as a farce created by white people to annul the struggle of the black population (this second version would be on the rise, being defended by the black movements, which pleaded for its replacement by November 20, the date of the death of Zumbi dos Palmares); finally, the version called "criticism", with which José Murilo de Carvalho identifies himself, responsible for defending the maintenance of the importance of May 13, however, under a new perspective that seeks to privilege popular protagonism, including the reaction of the enslaved (this last version would be gaining prominence, especially in academic circles). [17]

The strong position of denying May 13 by a part of the black movement on the occasion of the centenary, can be seen, according to sociologist Flavia Rios [18], as one of the milestones of contemporary anti-racist struggle. For the researcher, the manifestations that questioned the celebrations related to that date gained a great reach, above all, due to the symbolism of the moment and due to the process of drafting the new constitution. Using reflections from other authors (such as Lilia Schwarcz and Jacob Gorender), Flavia Rios shows the impacts of black movement interventions and how the marches that were organized that year were marked by a rejection tone, that is, they denounced that, in fact, abolition never happened.

Other researchers turned to investigating the repercussions of the "celebrations" (or their rejection) in the press at the time. When analyzing part of the material published by some of the main periodicals in Rio and São Paulo in 1988, Maria Valéria Barbosa and Henrique Cunha Jr. [19] identified the main themes related to the centenary of abolition that were treated in newspapers at the time and at the same time, they compared their approaches with the discourse of the organized black movement. The authors highlight throughout the text some of the differences and similarities presented by the printed material on the subject. As a whole, they observed that the ideas conveyed in the journals of the two cities demonstrate a certain overcoming of the vision of "racial democracy" and of "mulatto Brazil", however, they emphasize that such publications are still products of an ideologically white and limited environment with regard to a more complex understanding of the racist structure that exists in Brazil.

And what did the samba schools say about the subject, considering the strained relations between them and the black movement? The dissonant aspects between these different groups had already been argued by Guilherme Faria [20]. The author says that although the bibliography on the black movement has not certified, or even ignored, the samba schools and the role they played in contesting social inequalities and defending the pride of being a black person in Brazil, it is necessary to recognize that such associations have been constituted, at least since the $1960 \mathrm{~s}$, in important voices emitting history, culture and the defense of black people interests in the country.

Regardless of whether the verses of the sambas-enredo express a more critical and explicit discourse against racial prejudice or not, the very creation of these associations was a response to the marginalization suffered by them since the abolition of captivity in 1888 . In this sense, the creation of these societies added up to others that already existed, aiming to guarantee places of socialization and aggregation of this poor and excluded population. These associations ensured, therefore, the opportunity to share knowledge, exchange experiences, make friends, arrange affections and share the subculture of the group itself, linked to the Afro matrix of which it was tributary, as we will see in the next topics.

\section{The Carnival of the Centenary of Abolition in Rio de Janeiro}

The parades of Rio de Janeiro samba schools at the 1988 Carnival, as already mentioned in the introduction, were marked by thematic choices of sambas-enredo that echoed the centenary of slavery abolition in Brazil. In this respect, different carnival associations have paid tribute to black people for their services or made some kind of reference to Afro-Brazilian culture as well as the slavery abolition in Brazil, even if the motto of their presentations did not properly address the theme.

It should be considered, however, that only three schools of the so-called special group were dedicated exclusively to the black movement theme in the carnival of 1988, and they were: Unidos de Vila Isabel, Estação Primeira de Mangueira and Beija-Flor de Nilópolis. Therefore, the focus of our analysis will be these associations. In fact, all three won the first positions of the competition in that year, as we can see in the table below that shows the final classification of this competition:

Table 1. Final classification of the samba schools parades (Group 1) of the Rio carnival of 1988.

\begin{tabular}{lll}
\hline & Samba school & Samba-enredo \\
\hline 1st & Unidos de Vila Isabel & Kizomba, festa da raça * (Kizomba, a race party) \\
2nd & Estação Primeira de Mangueira & 100 anos de liberdade, realidade ou ilusão?* (100 years of freedom, reality or illusion?) \\
3rd & Beija-Flor de Nilópolis & Sou negro, do Egito à Liberdade * (I'm black, from Egypt to Freedom) \\
\hline
\end{tabular}




\begin{tabular}{lll}
\hline & Samba school & Samba-enredo \\
\hline 4th & Acadêmicos do Salgueiro & Em busca do ouro * (In search of gold) \\
5 th & Portela & Na lenda carioca, os sonhos do vice-rei * (In the Rio legend, the dreams of the viceroy) \\
6th & União da Ilha do Governador & Aquarilha do Brasil (Watercolor island of Brazil) \\
7th & Império Serrano & Para com isto, dá cá o meu * (Stop it, give it back) \\
8th & Caprichosos de Pilares & Luz, câmera e ação (Lights, camera and action) \\
9th & Mocidade Independente de Padre Miguel & Beijim, beijim, bye bye Brasil (Little kisses, bye bye Brasil) \\
10th & Tradição & O melhor da raça, o melhor do carnaval* (The best of the race, the best of the carnival) \\
11th & Estácio de Sá & O boi dá bode (The ox goes wrong - Literally: The ox gives a goat) \\
12th & São Clemente & Quem avisa amigo é * (He who warns is a friend) \\
13th & Unidos da Tijuca & Templo do absurdo - Bar Brasil (Temple of the absurd - Bar Brasil) \\
14th & Unidos da Ponte & O bem amado Paulo Gracindo (The beloved Paulo Gracindo) \\
15th & Unidos do Cabuçu & O mundo mágico dos Trapalhões (The magical world of Trapalhões) \\
16 th & Imperatriz Leopoldinense & Conta outra que essa foi boa* (That's a good one, tell me another!) \\
\hline
\end{tabular}

Source: Prepared by the author from information gathered from the Galeria do Samba website $<\mathrm{http}: / /$ www.galeriadosamba.com.br/ $>$; and at the LIESA Cultural Department $<$ http://liesa.globo.com/>. Accessed on: Oct. 2, 2019. $\left.{ }^{*}\right)$ sambas-enredo that presented a connection with black movement themes.

It is noteworthy that all the sambas-enredo that appear in the table marked with an asterisk $(*)$ presented, either in the synopsis or in the lyrics of the composition, some kind of mention or connection with the black movement theme. Therefore, it is possible to say that most of the sambasenredo presented in that year (nine, to be precise) dialogued, in some way, with questions related to the centenary of abolition.

Analyzing the available sources about this carnival (synopses, samba lyrics, parades photos and videos) and considering the objectives of this article, it is possible to divide the sixteen sambas-enredo listed in Table 1 into three groups, according to their proximity in relation to the black movement theme. Such grouping was systematized in the chart below:

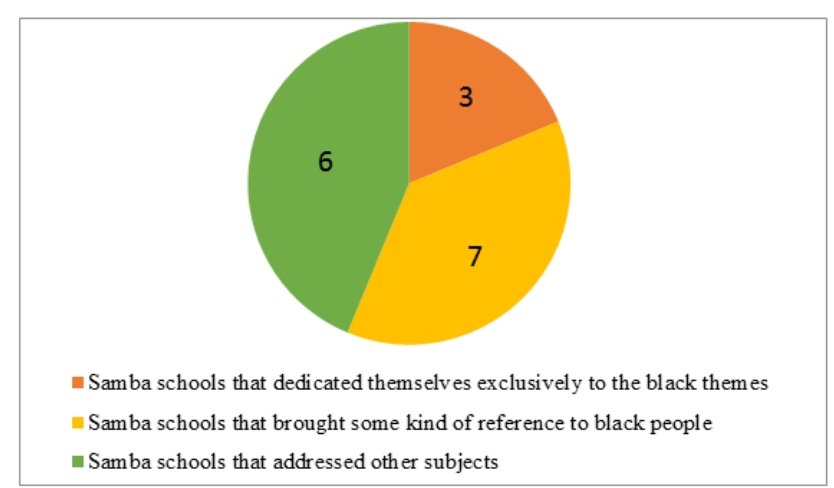

Figure 1. The black presence in themes of Rio de Janeiro samba schools at the 1988 Carnival.

Source: Prepared by the author with information gathered from Galeria do Samba website <http://www.galeriadosamba.com.br/>; and the LIESA Cultural Department $<$ http://liesa.globo.com/>. Accessed on: Oct. 2, 2019.

Samba schools that did not address the theme of blackness are grouped in green. That is, they are associations that engaged on other issues and did not touch, even indirectly, on issues involving black people or the abolition of slavery in the country. Note that this group brings together six associations, which leads us to reflect on the relevance of the theme and the date itself to the samba schools, after all, a significant amount of them did not adhere to the theme, since there was no official imposition or recommendation by
LIESA, as occurred, for example, in the carnival of the year 2000 (as a result of celebrations of the 500th anniversary of Brazil's "discovery").

The sambas-enredo belonging to the yellow group, on the other hand, are those that inserted some kind of "tribute" to black people or at least cited something related to their freedom, even though they had various subjects as their motto. Take, for example, the samba school Acadêmicos do Salgueiro - an association recognized for developing different themes related to Afro-Brazilian culture and homages to black personalities since the 1960 s - which in the year of the centenary of abolition talked about the exploitation of gold and the human ambition for this precious metal throughout the ages. In this perspective, the gold cycle in Brazil and the participation of black captives in the mineral exploration were remembered by Salgueiro, and in addition, religious entities of African origin were also featured in the parade.

What is striking, however, is that Salgueiro in the following year (1989) proposed the samba-enredo "Black Temple in time of black consciousness" (Templo negro em tempo de consciência negra), developed by the carnival producers Luiz Fernando Reis and Flavio Tavares. The choice of the theme appears to be a response to criticism suffered by the school for not having considered a theme that was, in fact, focused on the Afro-Brazilian universe as did the first three places in the 1988 competition. The lyrics have a tone of justification for not choosing the theme of the previous year and they present the Vermelho e Branco (Red and White, as a nickname to Salgueiro for its colors) as a different association from the others, a kind of bastion of defense for black people and their culture not only in "specific" dates, as we can observe in the following translated passage:

"When everyone remembered the black people in 1988, we at Salgueiro will only do so in 1989 , not only because we are different, but also because it seems to us that the black movement, the black struggle does not end in 88 , it is greater than the centenary of this so-called freedom, of this false abolition. It is important that this flame does not go out and that in the 101st, 102nd, 103rd year of the liberation of slaves, equality is still proclaimed among black, mulatto and white people. That is why we say that Salgueiro is audacious, bold and different, because when 
this flame of struggle begins to cool down we will revive it, rekindle it with our evolution, our singing and dancing [...]" [21].

Finally, the third group that appears in the table (orange) gathers the sambas-enredo that approached the black movement theme in a more direct way, that is, they dedicated themselves to exalt the black people and their culture, they approached their historical struggle and their daily resistance, as well as, of course, singing about freedom. This was the case of the three schools already mentioned: Vila Isabel, with the samba-enredo "Kizomba, festa da raça" (Kizomba, a race party); Mangueira, with "100 anos de liberdade, realidade ou ilusão?" (100 years of freedom, reality or illusion?); and Beija-flor, with "Sou negro, do Egito à liberdade" (I am black, from Egypt to freedom). All three make it clear sambas-enredo, dancing and plastic art aspects were all influenced by the symbolism of the date, but this does not mean that they agree or defend the official version of abolition. This aspect will become clearer below, as we will look more closely at these three sambas-enredo.

Let's start this analysis, therefore, with the contest's winning school, Unidos de Vila Isabel, which won the first title of its history at the 1988 Carnival. Analyzing the television broadcast and the repercussion in the periodical press, we see that the "Azul e Branco" (Blue and White, the colors of Unidos de Vila Isabel) association made a parade that exalted the blackness and brought joy to the present audience. The theme taken to the streets was proposed by one of its most distinguished members, samba artist Martinho da Vila, and took shape through the plastic art work of the carnival artist Milton Siqueira (who, after falling ill, was assisted by two other carnival artists who completed the project: Paulo Cezar Cardoso and Ivalmar Magalhães).

The parade presented by Vila Isabel was a big surprise as the school faced many problems throughout the year of preparation for that carnival. The newly assumed president, Ruça, found an association with many problems to be solved, they were plunged into financial difficulties.

The word "Kizomba", present in the title, comes from Kimbundo (one of the languages spoken in Angola) and it means meeting/socializing with people who identify with each other. The proposal was for a big party, marked by the exaltation of black people and their culture. In the excerpt from the translated lyrics highlighted below, we see more clearly what the samba-enredo was about:

"Our Kizomba calls for a meditation on the black influence of universal culture, the situation of black people in the world, the abolition of slavery, the reaffirmation of ZUMBI DOS PALMARES as a symbol of Brazil's freedom. Inform yourself about revolutionary and pacifist leaders from other countries, bring yourself to a reflection on the participation of black people in Brazilian society, their anxieties, their religion, and protest against racial discrimination in Brazil and speak out against apartheid in South Africa, while eating, drinking, dancing and praying, because, above all, Kizomba is a festival, the festival of the Black race" [22].

As it is noticeable, this excerpt presents, in general, the school's ambition with the theme and, at the same time, invites a reflection on aspects that involve the condition of black people in Brazil and in the world. It is apparent the lyrics have a certain tone of manifest and that they protest against racism, besides denouncing Apartheid in South Africa. Zumbi dos Palmares is remembered as the great symbol of freedom in Brazil, and is also highlighted in the translated lyrics of the samba (composition by Rodolpho, Jonas and Luis Carlos da Vila):

"Thanks Zumbi! / The loud cry of the Palmares / That ran lands, skies and seas / Influencing the abolition / Zumbi thanks! / Today Vila is Kizomba / It's drumbeat, singing and dancing / Jongo and maracatu / Come little girl to dance the caxambu / Oh, oh, Nega Mina / Anastácia wouldn't let herself be enslaved / Oh, oh Clementina / Pagode is the people's party / Priest raises the cup / Summoning the masses / In this harmonizing event / People of all races / Sharing the same emotion / This Kizomba is our Constitution / So magical / Pray, ajeum and orixás / It has the strength of culture / It has art and bravery / And it's fexible / It makes your ideals true / And the pure beauty of your rituals / It comes Lua de Luanda / To light the street / Our headquarters is our headquarters / And may apartheid be destroyed / Thanks!" [23].

In addition to commemorating the centenary of abolition, Brazil in 1988 was immersed into the process of redemocratization that would be concluded with the promulgation of the new constitution that year. The presence of black people in society was rediscussed and the constitution brought significant advances for the black movement, such as the recognition of land ownership to the remnants of quilombola communities and the criminalization of racism. Religiosity, Afro-Brazilian culture and black resistance are highlighted in the lyrics of samba, and in the year when the new Brazilian Constitution was finally approved, Vila Isabel declared "This Kizomba is our constitution"[24].

In its plastic art development, African aesthetics predominated in the costumes and allegories of the school. With a limited budget, the narrative elaborated by the association was reproduced with the help of alternative materials, which, in the end, matched the proposed theme the use of straw, sisal and raffia fibres denoted the valorization of rustic themes and color shades close to beige and brown, mixed with the school colors. In addition, we see the use of fabrics that resemble animal skins, tribal-inspired prints and repeated use of beads and necklaces.

As we see in samba, Zumbi was not the only black leader exalted by Unidos de Vila Isabel. In the parade, the samba school presented some tripods that brought panels with the image of several black leaders of the world, recognized for their struggle. Among those honored were: Martin Luther King, Samora Machel, Agostinho Neto and Nelson Mandela.

Estação Primeira de Mangueira took to the avenue the samba-enredo "Cem anos de liberdade - realidade ou ilusão?" (One hundred years of freedom - reality or illusion?), which questioned whether the abolition in fact granted some freedom to black people. The defiant tone, which took over the parade of the "green and pink", was 
already present in the lyrics presented by carnival producer Julio Mattos. The text confirmed that the choice of theme was influenced by the symbolic date, that is, the commemorations related to the centenary of abolition, and it also drew attention to the suffering and the struggle of black men and women in pursuit of the so dreamed freedom.

When talking about the abolition of slavery, Mangueira was not restricted to the past, that is, it did not deal specifically with the historical episode. In fact, its focus shifted to the present by denouncing the reality of the black people at that juncture, associating the problems lived by them to an abolition that gave no guarantees to the freedmen. As we can confirm in the excerpt from the following translated lyrics:

"In modern times, the vast majority of black people came to live in the slums due to the lack of structure of the post liberation, given that they were not provided the minimum to face the new social reality. The slum is ready to explode, like a gunpowder barrel, with the whole community suffering, abandoned by the government $[. .$. Pharaonic works are not enough, what matters is shortterm solutions, with schools, food, minimum breathing conditions and opening up the labor market to black people" [25].

The samba-enredo (by Hélio Turco, Jurandir and Alvinho) follows the same idea of the lyrics - questioning if the Lei Áurea (Golden Law) really freed the black people, remembering Zumbi dos Palmares and noting that little has changed with the abolition, a black person that once suffered in the senzala, is now trapped in the misery of the slum:

"I wonder... / If the freedom has already dawned / Or if it was all an illusion / I wonder... / If the Lei Áurea that was so dreamed of / Signed so long ago / It was not the end of slavery / Today in reality / Where is freedom / Where is it that no one has seen it / Young man / Don't forget that the black people also built / The riches of our Brazil / Ask the creator / Who painted this watercolor / Free from the whip of the senzala / Stuck in the misery of the slum / I dreamed.../ That Zumbi dos Palmares returned / The sadness of black people is over / It was a new redemption / Lord... / Here's the fight of good against evil / So much blood has been shed / Against racial prejudice / Black people dance samba / Black people play capoeira / $\mathrm{He}$ is the king in the pink and green of Mangueira" [26].

Beija-flor de Nilópolis followed a similar train of thought and presented the samba-enredo "I am Black, from Egypt to freedom" (Sou Negro, do Egito à liberdade) in which it sought to portray the history and culture of black people. The samba-enredo sought in Ancient Egypt the roots of the black Brazilian, it also highlighted its tradition and wisdom and recalled the centenary of the slavery abolition in Brazil. The critical tone is visible in the lyrics of the composition (written by Ivancué, Claudio Inspiração, Aloísio Santos and Marcelo Guimarães) that highlighted the harsh reality to which black people were still subjected, true freedom was claimed and it was argued that equality between white and black people has not yet "dawned":

"Come here my love to tell now / The hundred years of liberation / The history and art of black slaves / Who lived in great affliction / [...] I am a black man / And today I face reality / And embracing the Beija-flor, my love / I claim true freedom / The sun has risen, it's gone / And the moon has come / I'm a black man, I've been a slave / And life goes on / Freedom has risen / But equality has not [...]" [27].

From the reflections presented about the parades held we saw that the samba schools took to the avenue sambas-enredo that on one hand exalted black people and their culture and, on the other, denounced the daily hardships faced by them, as well as their yearnings to change that reality.

Analyzing the lyrics of the sambas-enredo, we realize that, unlike previous periods, when the overwhelming majority of sambas favored the foretime (with themes related to the history and the memory of black people) [28], in the carnival of 1988 the optics is different, because the schools reveal a greater concern about the present time in which they were inserted and the possibility of changes for the future. This displacement can be easily observed, for example, in the fact that the three sambas use the word "today" in their lyrics, referring to the context in which they were inserted.

Another aspect to note is the use of the singular or plural form of the first person in some passages of the analyzed sambas. This feature eventually approximates and even causes greater identification between that reveler who is in the parade singing the samba and the content of the sambaenredo itself. As an example, we may cite passages such as: "I am a black man, I was a slave and life goes on" (Beija Flor), or "I dreamed that zumbi dos palmares came back" (Mangueira) and, finally, "Our headquarters is our headquarters, and may apartheid be destroyed" (Vila Isabel).

It is also necessary to consider that the parades focused on in this article are part of a broader set of sambas-enredo that dealt with different themes through a critical approach [29]. The critical tone is evident in the cases analyzed. Schools were concerned not to endorse the official narrative, extolling the Lei Áurea (Golden Law) or Princess Isabel (which was very common in previous decades), instead, they questioned this supposed "freedom", denouncing racial inequality and prejudice.

\section{The Samba Schools in São Paulo City Discuss the Centenary of Slavery Abolition}

In 1988, the associations of black people from São Paulo, capital, besides calling out against slavery, they emphasized their cultural origins in the themes brought to their carnival parades. This perspective was recursive in their trajectories. They exposed sambas-enredo with themes that reported to Mother Africa. An incisive example can be found in the year 1982 when several prestigious and visible samba schools from Group 1 favored themes referring to their African roots. The theme was recurrently approached and it would not be different in 1988, the year of the centenary of the slavery abolition in Brazil. The Special Group, named this year, presented twelve sambas-enredo, three of them alluding to the 
subject. The schools that were concerned with discussing the meaning of freedom were Unidos do Peruche, Barroca da Zona Sul and Colorado do Brás. Table 2 shows the name of these groups, the title of the samba-enredo and its classification, resulting from the judgments of their parades.

Table 2. Final classification of the samba schools parades (Group 1) of the São Paulo carnival of 1988.

\begin{tabular}{lll}
\hline & Samba schools & Name of samba-enredo \\
\hline 1st & Vai Vai & Jorge Amado, a história de uma raça brasileira (Jorge Amado, the history of a Brazilian race) \\
2nd & Mocidade Alegre & O cientista poeta Vanzolini (The poet scientist Vanzolini) \\
3rd & Camisa Verde e Branco & Convite para amar (Invitation to love) \\
4th & Nenê da Vila Matilde & O poeta falou Zona Leste somos nós (The poet said we are the East Zone) \\
5 th & Unidos do Peruche & Filhos da Mãe Preta (Children of the Black Mother) \\
6th & Rosas de Ouro & Carvalho, madeira de lei (Paulo Machado de Carvalho) (Oak, a hardwood (Paulo Machado de Carvalho) \\
7th & Barroca Zona Sul & Nova mente (Again - Literally: New mind) \\
8th & Acadêmicos do Tucuruvi & No reino da fantasia fui rei por um dia (In the realm of fantasy I was king for a day) \\
9th & Colorado do Brás & Catopês do milho verde, de escravo a rei da festa (Catopês of green corn, from slave to king of the party) \\
10 th & Águia de Ouro & Menino da Lapa (Sargentelli) (A boy from Lapa (Sargentelli) \\
11 th & Imperador do Ipiranga & Sonha Brasil (Dream it Brazil) \\
12 th & Flor da Vila Dalila & Me engana que eu gosto (You could have fooled me) \\
\hline
\end{tabular}

Source: SASP - Sociedade Amantes do Samba Paulista. <http://www.sasp.com.br/A_CARNAVAIS.asp\#.WejskGhSyUk>.Acessed on: 20/09/2019.

In this table, in addition to the sambas-enredo that directly addressed the subject, other mottos of the Special Group samba schools focused on issues that valued black culture, such as Vai Vai and its samba-enredo "Jorge Amado, a história de uma raça brasileira" (Jorge Amado, the story of a Brazilian race) (1st place); and Flor da Vila Dalila association (12th place), whose very critical samba-enredo "Me engana que eu gosto" (You can fool me because I like it), unveils the promises unfulfilled by the country's elites. The Vai Vai samba-enredo highlighted in the lyrics the titles of Jorge Amado's books with their characters that focused on black people and their survival difficulties. On the other hand, the theme verses of the samba school Flor da Vila Dalila highlighted unemployment, hunger, false vows regarding land reform, the abandonment of indigenous people and minors. Although the samba-enredo did not connect the ailments pointed out to the situation of the black people, it is known that this outlined picture corresponded to their condition in the country.

Historian George Andrews [16] already mentioned previously analizysed this centenary from different angles. For example, the author pointed out that the insertion of black people in the formal labor market occurred in lowpaying subordinate posts. He also noted the wage differences between black and white workers in the exercise of the same function.

These situations of discredit and exclusion, Andrews warns, were repeated to the group in all aspects of the country's political and social life. At the heart of the issue were racial discrimination and prejudice that still remained veiled in some situations and explicitly day-to-day for the black population, despite the existence of the Afonso Arinos Law that penalized racists.

The Barroca da Zona Sul samba school exhibited the samba-enredo "Nova mente" (New mind), written by composers Dorinho Marques and Márcio Madrugada. The following verses give the dimension of this reading and the values and protagonists that were recovered to evaluate such a milestone.

"My samba / Life and art of these people / The Barroca again / In a multicolored setting / Mother Africa / Her mystery \& magic / In the light of poetry / It's beauty and splendor / See Zumbi / I reaped the fruit he left / Freedom the seed / Germinated the "new mind" / Oxalá enlightened / Oh my mother Little Girl / Look after us / Clementina de Jesus / In the sky echoes her voice / Dark roots / What a spring seduction / Casa Grande e Senzala / A book by Gilberto Freire / A portrait of Brazil / What king am I? / In a cinnamon country / Joy of thousands / I've crossed the seven seas / I'm king of the catwalk / Here comes Barroca / in high spirits / crowning the black people / it's an original party" [30].

In this samba, the school of multiethnic composition reread its African roots and celebrated Zumbi, the personality that established itself as the founding father of the struggle for freedom of black people, guaranteeing the present generations its fruits. Tributes were also given to Mãe Menininha (mother of saint) and Clementina de Jesus (singer), women who became referents, because they are perceived as mythical entities and guardians of their religious and cultural values. And also, Gilberto Freire, highlighting the book Casa Grande e Senzala.

The allegories brought African standards into costumes and floats, which featured sculptures referring to the honorees. And also floats with sculptures alluding to Mother Africa, with its peculiar characteristics, to mark the origin of the group. The characteristic animals of the region, such as zebras, had their stripes as inspiration for the allegories and were also represented in sculptures in one of the floats.

The G. R. E. S. Colorado do Brás Samba School, in this year of the centenary of the slavery abolition (1988), exhibited the samba-enredo "Catopês do Milho Verde, de escravo a rei da festa" (Catopês do Milho Verde, from slave to king of the party), by composers Dom Marcos, Roná Gonzaguinha, Edinho, Xixa and Minho. Its verses are as follows:

"It's a peaceful morning / That embraces and makes the skins more united / It's so beautiful / Races were not created, God only created lives / Quilombo spread his roots / And made his seed germinate / In rich mining lands 
/ From Milho Verde comes a song through the air / Group of legendary black people / Traditional Catopês / They make the celebration of the Rosary / Scenario of our ancestors / It is bambaquerê that makes the body swing / It is bambabará that shakes it back and forth / It is rue and guinea / Scaring all the lurking evil / Quilombo-shaped on the avenue / Colorado bustles in the main parade / (and comes) comes to show the whole world / That the black Brazilian / Sings free and makes his carnival / Singing love I will be / Because I'm happy / It's that happiness has no color" [31].

The theme turned to congada of hybrid cultural root (Portuguese and African) referred to the Catholic religious tradition [32]. It had been reframed by black people and was disseminated over the centuries by Grupo de Negros Catopês (Group of Black Catopês) which, according to legend, was chosen by Our Lady of the Rosary to be part of Festas de Agosto (August Feasts) in her honor in the town of Milho Verde, in Montes Claros, Minas Gerais [33]. The traditional representation in honor of the Saint was reiterated by the Colorado do Brás samba school in the centenary of the slavery abolition. By bringing this theme, the school presented itself on the catwalk as Quilombo that aimed to spread the seed of freedom, in line with the quilombola tradition. It was reaffirmed another principle by saying that "God did not create race but life," in a clear denial of colorbased racism and social boundaries.

Unidos do Peruche, with its samba-enredo "Filhos da Mãe Preta" (Sons of the Black Mother), was detached from a local reflection, expanding the dimensions of the struggle for freedom by establishing tributes to black leaders, Zumbi de Palmares, Luther King and Nelson Mandela. These personalities played a role in clashes on the American continent and in Africa, by rising against the barbarism of slavery, as did Zumbi. And in contemporary times, the continuation of the fight against its consequences, such as Nelson Mandela fighting against apartheid in South Africa and Luther King questioning the limitations of civil and political rights for black people in the United States of America. Their verses clarify the stature of these exclusions.

"Atôtô Oabaluaê / Atôtô Oabaluaê / Come here oh clarity / Peruche sings freedom / Ê! Mother Africa / spreading her children around the world / This banzo is so deep / that they awaken in a second / When walking happily / So many stars shining brightly / It's not Isabel's toy / Pixinguinha and Clementina / A force that dominates / a light that comes from the sky / Oiá, ieo / from the root to the most beautiful flower / Oiá, ieo / it is Zumbi it is Luther King and Mandella / Black gemstones / lead the boat to row / These beautiful people / brighten my singing / Quilombo / a free song echoed / Malê Gegê son of Zambi / Anuanas coming from Nagô / Children of Black Mother / grandchildren of Yoruba / Spreading across the world / extolling the Orixás" [34].

It can be seen, therefore, that the sambas-enredo analyzed brought distinct aspects to discuss the legacy of freedom experienced by the group, one hundred years after the rupture of the slave system. The allegory of a hand holding a broken chain is expressive to evidence the breaking of the shackles that held them in captivity. However, the popular poets, in the verses of the sambas-enredo, identified the scars of barbarism of the slave system in the social exclusion of black people in the post diaspora, in a transatlantic dimension and not just local, evidenced in several countries.

The sambas-enredo presented by the samba schools of São Paulo, as well as in Rio de Janeiro, constitute something that we can call "voices from the margins", in the sense proposed by Stuart Hall, as they point to the construction of narratives of affirmation of Afro-Brazilian identities that end up intervening in varied spaces of representation, demarcating "the result of cultural policies of difference, struggles around difference, the production of new identities and the appearance of new subjects in the cultural political scene"'[35].

It is also clear that there are other shackles, the prejudice and social exclusion against men and women of color that affect successive generations. Regardless, in their cultural representations they sought to insert themselves in different ways in Brazilian society, whether in profane parties such as Carnival or in those of religious matrix. In this sense, the samba performers continued to seek protection from their orishas and Catholic saints, such as Our Lady of the Rosary, among other saints, to ensure the path of the following generations with less exclusion and more peace, "love" and "happiness" because she "has no color".

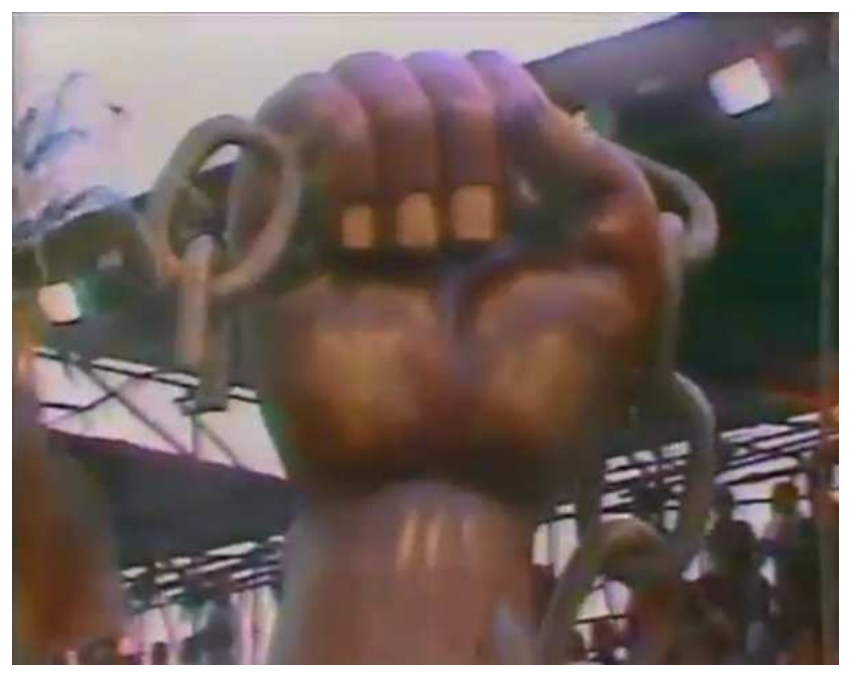

Figure 2. Sculpture of one of the floats from Unidos do Peruche. Sambaenredo: "Children of the Black Mother" (1988). Source: TV Cultura.

\section{Conclusion}

The interest of this text was to recover the reading made by the samba schools about the centenary of the slavery abolition and its possible consequences in contemporary times. The themes chosen by the carnival groups in the two cities focused reveal the objective of reaffirming traits and traditions of Afro-Brazilian culture. By singing freedom, samba schools highlighted the leading role of black leaders in 
Brazil and the world and denied any narrative that reduced black people to passive roles.

At the 1988 carnival, therefore, carnival groups, both in Rio and São Paulo, chose themes and produced sambas that shifted from hegemonic ideas such as the existence of a "racial democracy" in Brazil. When questioning old racist hierarchies and highlighting the problems of exclusion experienced by Afro-Brazilians, the lyrics of the compositions reveal the attempt to position themselves before the symbolic disputes that involve the narrative construction of the history of black people in Brazil. In this sense, Momo's festivities showed a certain harmony between the samba performers and the groups that militated in the black movements, but also pointed out political distance from those ideas that marked black militancy.

Regardless of the evidence present in their written and sound discourses, some questions remained underlying, such as the continuity and historicity of Afro-descendent identities. Would they be effective and lasting, considering the immediacy and intensity of the global cultural confrontations that began to interfere in Brazilian contemporaneity? Wouldn't the reiteration of Tradition, as Stuart Hall analyzes, be a response to "the challenges of forging a new selfinterpretation, based on the responsibilities of Cultural Translation"? Certainly these are issues that permeate the studies of Brazilian carnivals centered on the samba schools of the cities in focus.

\section{Acknowledgements}

This study was financed in part by the Coordenação de Aperfeiçoamento de Pessoal de Nível Superior - Brasil (CAPES) - Finance Code 001 (financing granted to Ynayan Lyra Souza).

Translation by: Rodolfo da Silva Alves

\section{References}

[1] MATHEUS, Letícia. Memória e identidade segundo Candau. Revista Galáxia, São Paulo, n. 22, p. 302-306, dez. 2011, p. 205. [Resenha: CANDAU, Jöel. Memória e identidade. Tradução: Maria Leticia Ferreira. São Paulo: Contexto, 2011, 219p].

[2] HALL, Stuart. A identidade cultural na pós-modernidade. $11^{\mathrm{a}}$ ed. Tradução: Tomaz Tadeu da Silva e Guacira Lopes Louro. Rio de Janeiro: DP\&A, 2006.

[3] Ibid, p. 72.

[4] RICOEUR, Paul. A memória, a história, o esquecimento. Tradução: Alain François (et al). Campinas/SP: Editora da Unicamp. 2007.

[5] SCHWARTZ, Stuart B. Escravos, roceiros e rebeldes. BauruSP: EDUSC, 2001.

[6] KARASCH, Mary. KARASCH, Mary C. A vida dos escravos no Rio de Janeiro (1808-1850). São Paulo: Companhia das Letras, 2000.
[7] MOURA, Clovis. Rebeliões da Senzala: quilombos, insurreições e guerrilhas. São Paulo: Zumbi, 1959.

[8] REIS, João José. A morte é uma festa: ritos fúnebres e revolta popular no Brasil do século XIX. São Paulo: Companhia das Letras, 1991.

[9] LARA, Sílvia Hunold. Escravidão cidadania e história do trabalho no Brasil. Proj. História: São Paulo (16), fev. 1998, p. 25-38.

[10] MATTOS, Hebe Maria. Das cores do silêncio: os significados da liberdade no sudeste escravista Brasil século XIX. Rio de Janeiro: Nova Fronteira, 1998.

[11] MOURA., op. cit., p. 251.

[12] MOURA., op. cit., p. 250.

[13] REIS, João José; GOMES, Flávio dos Santos. Liberdade por um fio. História dos Quilombos no Brasil. São Paulo: Companhia das Letras, 1996, p. 9.

[14] ANDREWS, George Reid. Negros e brancos em São Paulo. (1888-1988), Tradução: Magda Lopes. Revisão Técnica: Maria Lígia Coelho Prado. Bauru/SP: EDUSC, 1998.

[15] ANDREWS, George Reid. Mobilização política negra no Brasil, 1975-1990. História: Questões \& Debates, Curitiba, v. 63, n. 2, p. 13-39, jul./dez. 2015. [Editora UFPR].

[16] Ibid., p. 34.

[17] CARVALHO, José Murilo de. A Abolição aboliu o quê?. Folhetim - Especial 100 anos de abolição. Folha de São Paulo, n. 588, p. B 8-9, Sexta 13 de maio de 1988.

[18] RIOS, Flávia. O protesto negro no Brasil contemporâneo (1978 -2010). Lua Nova, São Paulo, n. 85, p. 41-79, 2012.

[19] BARBOSA, Maria Valéria; CUNHA Jr., Henrique. A imprensa e a produção/reprodução do racismo no Brasil. XVI Encontro anual da ANPOCS. Anais... Caxambu - MG, outubro de 1992.

[20] FARIA, Guilherme José Motta. As escolas de samba do Rio de Janeiro nos anos 60 e as narrativas sobre a história do negro na avenida. Faces da História, Assis-SP, v. 3, n. 2, p. 75-97, jul./dez. 2016.

[21] LIESA CULTURAL DEPARTMENT. Sinopse do enredo da Acadêmicos do Salgueiro, 1989.

[22] LIESA CULTURAL DEPARTMENT. Sinopse do enredo da Unidos de Vila Isabel, 1988.

[23] GALERIA DO SAMBA. Samba-enredo da Unidos de Vila Isabel, 1988, [emphasis added].

[24] SIMAS, Luiz Antonio; FABATO, Fábio. Pra tudo começar na quinta-feira: o enredo dos enredos. Rio de Janeiro: Mórula, 2015.

[25] LIESA CULTURAL DEPARTMENT. Sinopse do enredo da Estação Primeira de Mangueira, 1988.

[26] GALERIA DO SAMBA. Samba-enredo da Mangueira, 1988.

[27] GALERIA DO SAMBA. Samba-enredo da Beija-Flor de Nilópolis, 1988.

[28] AUGRAS, Monique. O Brasil do samba-enredo. Rio de Janeiro: Fundação Getúlio Vargas, 1998. 
[29] SOUZA, Ynayan Lyra. Críticas Carnavalizadas: as escolas de samba do Rio de Janeiro e os temas de seus enredos. 132f. Dissertação (Mestrado em História) - Faculdade de Ciências e Letras, UNESP, Assis, 2017.

[30] SASP - Sociedade Amantes do Samba Paulista. Sambaenredo da Barroca Zona Sul, 1988. [Composers: Dorinho Marques/ Márcio Madrugada].

[31] SASP - Sociedade Amantes do Samba Paulista. Samba-enredo da Colorado do Brás, 1988. [Composer: Dom Marcos, Roná Gonzaguinha, Edinho, Xixa and Minho].

[32] FERREIRA, Sueli Lopes de Queiroz. TRAJES DE FESTA: um estudo do figurino do Mestre de Catopês João Farias, de Montes Claros - MG. Dissertação (Mestrado) - Universidade Federal de Goiás, Faculdade de Artes Visuais, 2014.

[33] GENESTRETI, Paulo. Cultura popular e sensibilidade etnográfica: Vissungos e Catopês da comunidade de Milho Verde, Minas Gerais. Emblemas, v. 13, n. 2, 10- 25, Jul. Dez., 2016.

[34] SASP - Sociedade Amantes do Samba Paulista. Samba-enredo da Unidos do Peruche, 1988.

[35] HALL, Stuart. Da diáspora: identidades e mediações culturais. Belo Horizonte: Ed. da UFMG, 2003. 